23) Metzger, W. Psychologie 1940.

24）阿部孫四郎社会性のトポロジ的研究——社会 性, 社会的緊張および社会的㭙間場, 科学基礎論 研究, 1957, 12.
25)Helson, H., \& King, S. M. The Tau effect : An example of psychological relativity. $J$. exp.Psychol., 1931, 14, 202-217.

-1957.5. 29 受稿一

[心理学研究]正誤訂正

\title{
27 巻 5 号阿部論文
}

P. 333 左 註欄 4 行目
P. 336 左 Table 6
P. 339 右 23 行目
P. 340 左 $21-22$ 行目

詥

$\left[\mathrm{e}_{1}+\mathrm{P}_{1}+\mathrm{e}_{2}+\mathrm{P}_{2}=\mathrm{g}\right]$ 即亏 持続観察に於ける全時程

$\begin{array}{ll}\mathrm{t} & \mathrm{SD} \\ 4000 \sigma & 2.8\end{array}$

1) $2-1-2$

結論の中に前提を予想する
正

$\left[\mathbf{e}_{1}+\mathbf{p}_{1}+\mathbf{e}_{2}=\mathbf{g}\right]$ 即ち全時程

$\begin{array}{ccc}t & \tau & \text { SD } \\ 4000 \sigma & \infty & 2.8\end{array}$

1) $1-2-1$

結論を前提として予想する 